\title{
Textual practices in the new media digital landscape: messing with digital literacies
}

\author{
Lesley Gourlay $^{\mathrm{a} *}$, Mary Hamilton ${ }^{\mathrm{b}}$ and Mary Rosalind Lea ${ }^{\mathrm{c}}$ \\ ${ }^{a}$ Institute of Education, UK; ${ }^{b}$ University of Lancaster, UK; ${ }^{c}$ Institute of Educational Technology, \\ Open University, $U K$
}

(Received 15 May 2013; final version received 20 August 2013)

\begin{abstract}
This paper offers a working conversation between the authors about the uneasy relationship between literacy studies and learning technologies. We come from the field of literacy studies but from contrasting perspectives: from academic literacies and work on literacies and technologies in higher education; from an interest in media theory and the implications of digital mediation for the contemporary university; from everyday literacies in informal settings and a concern for the gaps between policy and practice. We illustrate our perspectives through reference to post-compulsory education, especially higher education, but intend our arguments to be of broader value to all sectors of education and learning. We argue that it is probably inevitable that terms such as literacy/digital/network will be taken up by different arenas of scholarship and practice to mean different things, but what is important is finding spaces to make visible the embedded and implicit understandings, assumptions and ideological positions that are carried by these terms. In the paper, we attempt to lay bare some of the tendencies in the different approaches and argue the case for building on these differences in our work rather than seeing them as paradigm contests. We suggest that it would be more generative to the field to acknowledge the richness and diversity of these different traditions, rather than attempting the impossible task of forcing them into a superficial reconciliation.
\end{abstract}

Keywords: literacies; digital; textual practices; learning landscapes; ethnographic

\section{Introduction}

This article is a working conversation between the authors about the uneasy relationship between literacy studies and learning technologies. We come from the field of literacy studies but with different perspectives: Lesley Gourlay from an interest in the media theory and the implications of digital mediation for the contemporary university, Mary Hamilton from everyday literacies in informal settings and a concern for the gaps between policy and practice and Mary Lea from academic literacies and work on literacies and technologies in higher education. We illustrate our perspectives through reference to post-compulsory education, especially higher education, but intend our arguments to be of broader value to all sectors of education and learning.

This position paper grows out of the significant, exhilarating but sometimes also uneasy and difficult conversations across disciplinary areas that are provoked when

*Corresponding author. Email: 1.gourlay@ioe.ac.uk

Research in Learning Technology 2013. (C) 2013 L. Gourlay et al. Research in Learning Technology is the journal of the Association for Learning Technology (ALT), a UK-based professional and scholarly society and membership organisation. ALT is registered charity number 1063519. http://www.alt.ac.uk/. This is an Open Access article distributed under the terms of the Creative Commons CC-BY 4.0 License (http://creativecommons.org/licenses/by/4.0/), allowing third parties to copy and redistribute the material in any medium or format and to remix, transform, and build upon the material for any purpose, even commercially, provided the original work is properly cited and states its license. 


\section{Gourlay et al.}

scholars researching digital learning technologies meet those working from a literacy studies tradition. The conversations we are engaged with are part of the effort to understand the significant shifts in practices of communication, learning and meaning making that are currently taking place. Claims for these shifts range from the banal to the utopian, and they often trade in binaries such as 'digital natives' versus 'digital immigrants,' online versus offline, and characterising both the 'predigital' and the 'post-digital' ages in ways that unhelpfully exaggerate the features of each.

One key arena for these conversations is that emerging around the idea of the digital university (Goodfellow and Lea 2013). Digital technologies are a key part of contemporary learning landscapes, offering many possibilities for changing pedagogies and forms of educational provision. At the same time, literacy (popularly understood as reading and writing) remains key to formal education and training, both practically and symbolically. Educators are therefore required to draw on both print and digital technologies to enable transitions into the future. We believe there is a real danger of reproducing old pedagogies and understandings of learning if the insights from scholarship in both traditions are not considered, assumptions surfaced and bridges built across them.

In this article, we aim to review the key differences, tensions, problematics and debates between the two traditions of literacies and learning technologies research. In particular, we are speaking to the increasing numbers of practitioners who find themselves working at the interface of literacies and technologies and who may have very few opportunities to examine the taken-for-granted presuppositions which underpin their work. We aim to marshal the arguments about the importance of looking carefully at how these two traditions intersect and what each brings to our understanding of learning and meaning making. We suggest that the key elements from the critical theoretical tradition of literacy studies, described in this article, should be integral to discussions of new media and new learning. Furthermore, the term 'literacy' (or 'literacies') itself needs to be carefully reconsidered in relation to these discussions since it is constantly being parted from its root meanings and used in multiple, confusing ways, as we illustrate in this article.

\section{New Literacy Studies and the digital landscape for learning}

We argue here that what we will call the 'New Literacy Studies' approach (NLS), a particular theoretical paradigm that has gained recognition over the last 30 years, has crucial insights to offer the study of learning with new media. In this section, we explain the particular insights of this approach, which has defined itself against earlier, cognitivist, individual skill-based models of literacy. These cognitivist models have their parallels in current attempts to solidify and standardise the field of digital competences (discussed in detail by Lankshear and Knobel 2005). We see such attempts as amounting to the 'enclosure' of the diverse landscape of digital practices and argue that the perspective advanced through the NLS can show a different, more inclusive and more productive way forward. We summarise here what we see as some of the key insights of the NLS in relation to a digital landscape for learning.

(1) Multiple literacies exist and need to be recognised rather than a single universal standard that normalises one narrow set of operational competences. In insisting on this, the NLS challenges the modernist, positivistic 
approach embedded in such singularities and asserts the situated nature of digital practices, which cannot be reduced to the acquisition of universal skills by individuals. It resists the enclosure of the digital by institutional concerns and agendas, asserting the importance of looking at digital practices wherever they occur. The NLS approach has also resisted the idea that a literacy practice should be correlated with a specific channel of communication - thus, a particular literacy practice could be carried by a digital medium, by the printed word or by engraving, by hand, in stone (think, e.g. of the textual practices of memorialising that can be realised through digital archives, obituaries and monuments).

(2) It is essential to take an historical view, interrogating changing notions of what counts as literacy and acknowledging what Selfe and Hawisher (2004) have called the 'layering' of technologies in everyday life. They suggest, 'New forms of literacy don't simply accumulate. Rather they have life spans: they emerge, they overlap and compete with pre-existing forms; they accumulate, significantly, perhaps, in periods of transition, but they also eventually fade away' (Selfe and Hawisher 2004, p. 213). The significance of this historical sensibility is to take the longer view of the emergence and significance of digital technologies, to examine them in relation to other communication technologies that may be rising or falling alongside them and to see this as an unfinished story whose outline - clouded by both utopian and dystopian visions - is barely discernible as yet. In adopting this approach, the NLS also makes connections with wider disciplinary areas of social history, media and communication studies and social informatics (Briggs and Burke 2010; Graff 1987; Haythornthwaite and Wellman 2002).

(3) The NLS emphasises informal learning in everyday practices embedded in networks of support, and how this relates to formal educational contexts. In particular, it identifies the significant people and agencies that mediate or 'sponsor' change through discouraging or promoting engagement with specific media (see Brandt 2009). Sponsors of learning are found in all domains of social life and significantly shape practices through their role in facilitating activities and offering access to particular skills and material things needed for learning. Such agents may be found in workplaces, businesses, intergenerational and cross-cultural exchanges as well as educational settings.

(4) The NLS draws our attention to the textual and semiotic aspects of learning and using digital media, and how meanings are represented and accessed via media of different kinds (e.g. Baynam and Prinsloo 2001). This textual focus counters the metaphorical appropriations of literacy to many different sites of social practice, where it becomes synonymous with general capabilities (e.g. emotional literacy and financial literacy) and loses both the textual and practice foci of the original term. The NLS highlights the central roles, both functional and symbolic, that textual practices play in education. Textual analysis for learning is now carried out within digital and printed media as well as face-to-face interactions which are often composed of talk coordinated around one or more texts (Lillis 2009).

(5) This approach brings an ethnographic sensibility to the study of communication technologies and has developed operational concepts for observing and recording local enactments of literacy practices (e.g. events, recurring 
procedures and routines - see Barton and Hamilton 2012). Use of these concepts keeps contextual detail to the fore, along with close observation of empirical examples rather than rhetorical claims. The aim is to access participants' perceptions and meanings in order to illuminate observed behaviour in relation to literacy practices. In its ecological approach, it focuses on the performance of literacy events and the roles of all participants, not just learners. The practices of teachers, assessors and administrators are thus implicated in the shaping of educational processes, so administrative and academic systems become an essential part of the picture that needs to be explored in research.

(6) Finally, and most importantly, the ecological approach of literacy studies demonstrates how texts are crucially implicated in the ordering of social life and relations of power. Empirically, it does this by tracking the institutional life of texts, practices and technologies within organisational settings (Lea and Stierer 2009). By selecting pivotal events, researchers can follow the threads outwards to broader aspects of social practice - what Scollon and Scollon (2004) call nexus analysis. Within formal education, this sheds light, for example, on the role of textual artefacts in formal assessment processes, both administratively and pedagogically, and in determining what knowledge is to count in the ordering of people and how evidence of this knowledge is assembled (Tummons and Hamilton 2012). It can also illuminate our understanding of the potential of digital technologies to facilitate extensive surveillance through the collection and processing of large amounts of data from the ongoing activities of teachers and students. This potential can be called into the service of business management systems in different ways, depending on the ideology and goals of powerful institutional groups (Williams 2013).

Similar to all theoretical frameworks, although the NLS has generated considerable insights, it also has limitations which are brought into sharper focus when viewed from the perspective of the field of learning technologies. First, the NLS is strongly rooted in linguistics and social semiotics and has had to work hard to pull away from traditional disciplinary assumptions. There is still a tendency to 'bracket off' materiality within NLS discussions and to reduce the notion of cultural artefacts in learning to a consideration of texts. There is still a strong interest in the verbal, and what participants say about their engagement with texts can hold more sway with researchers than a detailed examination of the multimodal nature of textual practice. Some NLS researchers have retained a focus on face-to-face interactions (the traditional stalking ground for linguists and ethnographers) and paid rather less attention to the virtual spaces of digital media, although there are other notable strands of work within the field that have moved a long way in this direction (e.g. Jewitt and Kress 2003; Lankshear and Knobel 2008; Goodfellow and Lea 2007; Lea and Jones 2011; Leander and McKim 2003; Pahl and Rowsell 2010; Williams 2009). Traditional disciplinary baggage and binaries are challenged by digital learning technologies, and literacy researchers in this field have strong affinities with and can conceptually and methodologically account for these new configurations of space and time, semiotic modes and materialities, which are the stuff of online learning. 


\section{Academic literacies, learning and technologies}

Academic literacies as its own field of enquiry built on the NLS within a particular historical moment in the 1990s (e.g. Baynham 2000; Ivanic 1998; Lea 1994; Lea and Street 1998; Lillis 1997, 2001). This was at a time when hopes for the potential of a widening of higher education, and issues of equity, access and participation, were driving the shape of the sector internationally, although at the beginning of the 21 st century this focus was increasingly being surpassed by the commodification and marketisation of a global higher education. It is impossible to separate these developments from the rise of digital technologies - that is, the broader social, economic and cultural changes associated with digital technologies have gone handin-hand with a market-oriented development of the sector. This changing climate has placed increasing value upon more pragmatic orientations towards knowledge and learning, which in many respects contrast markedly with those of the more critical approaches, which characterise the NLS and its concern with power and authority around textual practice. In this respect, a literacies perspective sits uneasily with many of the more 'visionary' views suggested by work in learning technologies (e.g. Conole 2008; Weller 2009). Whereas the field of learning technologies broadly assumes that digital technologies have the potential to directly influence learning, the NLS is more concerned with an examination of the range of different ways that participants make sense of the environment in which they are learning and making meaning, without making any prior assumptions about the potential implications of technologies. Although there are evidently connections and overlaps between these different perspectives, at a deeper epistemological level there are fundamental contradictions between them, in part arising from the contrasting approaches and value placed upon theoretical work and engagement in critical enquiry in the two fields.

Although theory has played a part in learning technologies research, the field as a whole has not tended to prioritise the development of critical standpoints and deepening understandings of situated practices, and, arguably, as a result mainstream work in learning technologies has generally sidestepped debates around power, authority, identity and meaning making. Its concern has been more focused primarily on the ways in which technologies might drive and change learning, and on supporting teachers and learning in using digital technologies (Beetham McGill and Littlejohn 2009). The mainstream of the field has generally continued to subscribe to a 'skills' paradigm as the dominant means by which to understand student practices around technologies, arguably taking a somewhat techno-rationalist stance towards the use of technologies and applications at a generic level, with little explicit focus on situated social practice, or indeed on the uses of technologies for reading and writing, despite the fact that these are practices central to the work of the academy.

This may account for why it has proved difficult to converse across these two distinct domains underpinned by very different epistemologies and linked to different agendas for research; the one is focused upon a critical and theorised approach to learning and literacies, and the other more pragmatic. Our task here is not to iron out these differences but to understand where they conflict and how they might be usefully aligned with each other conceptually, methodologically and practically. 


\section{Gourlay et al.}

\section{Talking past one other?}

One of the challenges of working in this area - where technologies and literacies rub up against one another - centres on what might be perceived to be apparently trivial differences in terminology. As suggested in this article, we believe these reveal more fundamental mismatches in terms of underpinning theory, focus and ideology. The NLS was itself founded on a series of distinctions in terminology and some crucial redefinitions of key (supposedly 'common-sense') concepts. The foundational distinction was made in terms of how 'literacy' itself was understood, with work in social anthropology (e.g. Brice-Heath 1983; Street 1985) and critical linguistics (e.g. Gee 1990) questioning established concepts surrounding what the term 'literacy' referred to and suggesting the alternative term 'literacies' to signal the plurality of practices. This particularly challenged the notion of literacy as a single, universal cognitive quality residing in the individual, instead conceiving of it as a set of situated social practices. This realignment broadened the scope to include shared social and material practices taking place around texts, and it also saw literacy practices as implicated in the enactment of power and reproduction of social privilege. As discussed in this article, a further distinction was made in Lea and Street's (1998) definition of the concept of 'academic literacies,' where a challenge was mounted to the notion of 'study skills,' questioning the extent to which student writing practices could be meaningfully separated from situated disciplinary practices and forms of meaning making. The concept of 'study skills' was seen as essentially a deficit model, with the alternative framing of academic literacies viewing the development of writing as an expected part of learning how to make meaning in diverse, often multidisciplinary social contexts. What both redefinitions have in common is that they view literacy primarily as social practice, with an emphasis on its situated, non-generic and also political nature. This orientation has led to various strands of work in the field, including a focus on social groups that have been traditionally marginalised by dominant literacy practices (e.g. Ivanic 1998; Lillis 2001; Thesen and Van Pletzen 2006).

As alluded to here, until relatively recently, academic literacies as a field of study appeared somewhat slow to respond to the digitally mediated world of higher education. We speculate that this could be a result of the pull of the field back to its examination of higher education's gatekeeping activities around high-status, authoritative and powerful texts, and also due to the dominance of the focus on print literacies, making it difficult for researchers to see beyond these to digital and associated textual practice. Additionally, although technologies are always implicated in literacies, they have become so black boxed (Morgan, Russell, and Ryan 2000) that researchers have paid little direct attention to them. Unsurprisingly given their familiarity, we have looked straight past pens, paper and blackboards and, similarly, academic literacy researchers have not 'seen' digital technologies in practice. It could also be argued that the attention given to student struggles with assignment writing and the micro-attention paid to the detail of student text production and lecturer feedback have meant that the field was somewhat slow to pick up on the shift towards increased use of digitally mediated texts and inscription practices. More recently, however, an interest in this shift has brought the work of some academic literacy researchers into a closer relationship with learning technologists (e.g. Goodfellow and Lea 2007; Lea 2007; Lea and Jones 2011; Williams 2009) and has generated a range of other work applying a broader literacies perspective to educational 
engagement with digital media (e.g. Carrington and Robinson 2009; Steinkuehler 2007). We recognise that in the United States, with its history of rhetoric and composition studies, attention to the relationship between writing and technologies has a much longer history - although this has not necessarily been through a literacy lens. As Williams argues, as a result of the advent of digital technologies, 'scholars in rhetoric and composition have opened for the first time in centuries, fundamental questions of composing and distributing texts' (Williams 2009, p. 15). He draws on the work of Welch (1999) and Zappen (2005), but as early as 1990 Cooper and Selfe (2009) were making related arguments about the use of technologies - in this case, computer conferencing - and the opportunities that these offered students to develop internally persuasive discourses which challenged the dominant conventions and relationships of the writing classroom.

Meanwhile, the literature in learning technologies shows a striking lack of recognition of the centrality of texts to learning technologies, perhaps another indication of the extent to which the strongly textual nature of education is naturalised and therefore rendered implicit in educational research and theory. This is perhaps not surprising when, as we have noted in this article, academic literacy researchers themselves have been slow to engage with the textuality of digital practice. For example, the (now ubiquitous) use of the virtual learning environment (VLE) is a topic which has generated a large literature in learning technologies, but with little acknowledgement that the VLE is primarily centred on the storage, organisation and generation of texts - such as PowerPoint slideshows, Word documents and discussion boards (see Williams 2013).

\section{'Digital literacies': ambiguous and infinitely elastic?}

As noted here, in education and society more broadly, the concept of 'literacy' has been applied to an increasingly wide range of contexts, leading to formulations such as 'media literacy' or 'computer literacy.' These terms are used to refer to a kind of practical (and supposedly transferable) 'know-how,' ironically not dissimilar to the notion of 'skills' which literacies had sought to overturn. The specific formulation 'digital literacy' was coined by Gilster (1997) and seems to have its provenance in this 'know-how' sense of the word. The more recent use of the plural 'digital literacies' points to an awareness of the NLS, which has favoured this form to emphasise the non-generic and multiple situated nature of the concept (see e.g. Lankshear and Knobel 2008). However, despite this, the notion of skills persists in the formulation 'digital literacy skills.'

This can lead to a situation in which NLS-influenced researchers and practitioners and those with a 'skills' orientation appear to be using the same term, but in fact are 'talking past one another' as they may be referring to very different clusters of foundational concepts. This is not to suggest a clear division, as both fields are heterogeneous areas of study with many contentious viewpoints and critical dissenters from the mainstream. Nevertheless, mismatches in understanding of the term 'digital literacies' remain apparent. It is for this reason that we feel this topic is worthy of detailed consideration - as an uncovering of these apparently minor terminological differences could in fact be crucial in moving these two fields of enquiry and practice closer together.

It is important to note that an uncovering of difference will not (and should not) necessarily lead to resolution - it seems likely that this complex and multidisciplinary 


\section{Gourlay et al.}

area of enquiry will always be to some extent ambiguous and 'messy,' perhaps reflecting the broad range of linguistic, sociological and technical issues and potential foci of attention. There are also clearly professional investments and identities centred on particular concepts, which for historical, cultural and epistemological reasons may be deeply embedded. We maintain that sustained attention to the (often implicit) theoretical, conceptual and methodological apparatus of this area is imperative, if we are to move to a more nuanced and mature understanding of digitally mediated engagement with texts in education.

One response to this messiness of terminology has been the attempt within learning technology to establish taxonomic definitions of digital literacies, breaking the concept into constituent elements. In their report on the JISC-funded 'Learning Literacies in a Digital Age,' Beetham, McGill and Littlejohn (2009) define a broader concept of 'ICT/computer/digital literacy' that is composed of the following: 'keyboard skills, use of capture technologies, use of analysis tools, use of presentation tools, general navigation/UI skills, adaptivity, agility, confidence/exploration' (2009:5). This definition combines some very specific technical 'skills' with a list of desired or target personal attributes of students, and in this regard it perhaps exemplifies the ambiguity of the term, which arguably is used here both as a 'tick-list' and a 'wish-list'. In a further example, Belshaw (2012) isolates what he terms the ' 8 elements of digital literacies,' which he lists as 'cultural, cognitive, constructive, communicative, confident, creative, critical and civic.'

This list (and Belshaw's discussion) acknowledges the social and collective nature of literacies, and is neither skills based nor technologies driven. However, it is striking that the eight elements refer primarily to what appear to be desired qualities to be associated with the individual idealised 'user,' rather than to the practices they are expected to engage with. Belshaw's analysis originates in research conducted in schools, which perhaps accounts for the focus on digital literacies as a set of attributes to be attained or worked towards. In this regard, this goal-oriented and rather ideologically loaded reading of 'digital literacies' appears to have morphed into a convergent expression of future achievement or aspiration. This echoes the associated move in a range of universities worldwide to structure curricula around generic graduate attributes or indeed 'literacies.'

These uses of the term are somewhat ironic, given that the foundation of the NLS and academic literacies argument was the need to focus on what people actually do in situated practice, challenging the validity of a focus on the generic and the 'transferable.' Early work also sought to move us away from the notion of literacy as an ideal set of abstract standards to strive for, a stance which inevitably positions students (and staff) as in deficit. However, the persistence in the mainstream of both a skills focus and a preoccupation with desired personal qualities of students may also point to one of the central weaknesses of the NLS perspective - that it has perhaps been most effective when deployed as a critique, and most generative when used as a means of shaping a radical and questioning research agenda. At the same time, the elasticity of the notion of literacy has enabled it to be co-opted to serve a range of different agendas.

This might lead some to ask whether the concept of 'literacies' has lost its ethnographic and disruptive edge through its complex re-emergence and co-option in the messy term 'digital literacies.' If so, we may want to consider whether another way of framing the issues is now required in order to maintain what we would consider to be an essential research and developmental focus on the situated, 
political, day-to-day 'doing' and 'being' involved in digitally mediated engagements with texts. A perspective is needed that retains this situated, critical perspective, distinguishing it clearly from the rhetorical use of the term 'digital literacies' to promote competency-based agendas that are aligned with institutional and organisational imperatives (see Goodfellow 2011; Lea 2013). Without such a framing, the danger is that there will be no challenge to the strongly normative perspective on academic practice which we argue is encapsulated in the present use of 'digital literacy/ies' to signal general competency and skill. Deficit models already hold sway within education more generally and commonly underpin calls to 'upskill' teachers as 'digital immigrants.' This is something we believe that we need to step back from if we are going to avoid re-enacting a deficit model of teaching and learning, this time around the digital. In our final section, therefore, we suggest a possible framework for moving beyond the deficit model and the unhelpful binaries it rests upon.

\section{Implications and future directions}

For some while, literacy researchers have been looking to other theoretical frameworks to complement their work (e.g. Clarke 2002; Hamilton 2011; Lea 2004; Pardoe 2000), particularly when considering new contexts. One of the most promising is the possibility offered by perspectives from science and technology studies, notably actor-network theory (ANT) or what is sometimes called 'material semiotics' or 'a sociology of translation' (Hamilton 2011). Law (2009) suggests that material semiotics is a kind of toolkit that can be understood as a powerful set of 'devices for levelling divisions which are usually taken to be foundational' (p. 147). His interest is in the ways in which behaviours, practices, artefacts, technologies and texts all work together in both visible and hidden ways within networks. Exploring the configuration of different networks offers a different perspective from that normally taken by literacy researchers, who have tended to focus on individual actors' textual practices and the implications of this engagement for their own processes of meaning making and identity formation (e.g. Ivanic 1998; Ivanic et al. 2009). As both Hamilton (2011) and Clarke (2002) argue, there is value in complementing a social practice view of literacy - with its focus around what individuals do with texts in practice - with an approach which looks at how things come into being through networks. Hamilton suggests that ANT is promising in this respect because it works with a dynamic view of social life which acknowledges power and contestation and assumes multiple perspectives. Its central metaphor is of 'an open field of competing social forces and projects that are continually shifting with alliances being formed and dissolved' (Hamilton 2011, p. 69). The epistemological assumptions behind this work are particularly compatible with the social practices perspective on literacy because of the similarity of ideas even though they may have different emphases and languages of description. The notion of 'network' identified in ANT can also be productively juxtaposed with the virtual networks written about in the learning technology literature (Castells 2010; Jones, Ferreday, and Hodgson 2008) which are dispersed alliances of people, machines and software tools configured by learning institutions (Orlikowski 2000).

Some work in the literacies field (e.g. Gourlay 2013) is drawing on the insights of media theorists such as Hayles, whose application of the concept of 'posthumanism' to digital mediation (Hayles 1999) also serves to undermine a series of taken-for-granted binaries such as human versus machine, like ANT seeing 


\section{Gourlay et al.}

meaning-making practices as generated by both human and nonhuman actors. Hayles' recent work (2012) proposes the notion of 'contemporary technogenesis,' in which humans and technologies are seen to be co-evolving. She argues for a new focus on 'comparative media studies,' a perspective which looks at how digital and print traditions intersect. Such approaches are promising in breaking down the increasingly unhelpful binaries mentioned in this article such as digital 'natives' versus 'immigrants,' and taken-for-granted essentialist distinctions such as teacher versus student, web-based versus print artefacts and fact-to-face versus virtual interaction. As Fenwick and Edwards (2010) remind us, these distinctions are actually no more than assemblages of myriad entities which order and govern practice in particular ways. This also applies to the strong binary identified and challenged in this article between NLS and learning technologies. Despite these fields of enquiry being both empirically and discursively precarious, they have the power to take on a 'thing-like' quality, responses to which then drive contrasting approaches to both policy and practice in profound and far-reaching ways.

We argue in conclusion that it is probably inevitable that terms such as 'literacy,' 'digital' and 'network' will be taken up by different arenas of scholarship and practice to mean different things, but what is important is finding spaces to make visible the embedded and implicit understandings, assumptions and ideological positions that are carried by these terms. This article has been an attempt to lay bare some of the tendencies in the different approaches and argue the case for building on these differences in our work rather than seeing them as paradigm contests. We suggest that it would be more generative to the field to acknowledge the richness and diversity of these different traditions, rather than attempting the impossible task of forcing them into a superficial reconciliation.

Recent work has moved in this direction, such as the (ESRC) 'Literacies in the Digital University' seminar series (ESRC 2011) and the associated blog (Goodfellow 2009), which sought to bring together literacy researchers and practitioners with learning technologists in a productive conversation about working together. Contributors to the edited volume that resulted from the seminars (Goodfellow and Lea 2013) bring theoretical, empirical and practitioner-focused accounts of work around literacies and technologies. These signal changing practices and relationships, for example between students and teachers, between academics and other professional groups and between learning technologists and library staff, in the 'digital university.'

Some strands of the JISC Developing Digital Literacies Programme (JISC 21012) have also moved in this direction. For example, the programme included a qualitative research study focusing on day-to-day student engagements with literacy practices using longitudinal multimodal journaling and interviews and applying an ANT and sociomaterial analysis. This study found that student literacy practices were intertwined in complex ways with their interactions with digital devices and texts, and also that devices and technologies were perceived to be agentive and powerfully constitutive of practices and identities (Gourlay and Oliver 2013; Gourlay, forthcoming). Such studies suggest that we need to continue to creatively expand the range of conceptual, empirical and practice-based approaches, in order to meet the complex challenges of working with texts, technologies and learning in a digital world. In terms of higher education, the answer in part lies in how we understand the nature of today's university and the ongoing and unresolved tension between the intrinsic value of disciplinary inquiry as a social and public good, and the role of 
the academy in a global higher education market meeting the needs of the digital knowledge economy.

\section{References}

Barton, D. \& Hamilton, M. (2012) Local Literacies: A Study of Reading and Writing in One Community, Routledge Classics, London/New York.

Baynam, M. \& Prinsloo, M., (eds) (2001) Language and Education, Special Issue New Directions in Literacy Research 15 (2-3).

Baynham, M. (2000) 'Academic writing in new and emergent discipline areas', in Student Writing in Higher Education: New Contexts, eds M. R. Lea \& B. Stierer, SRHE/Open University Press, Buckingham, pp. 17-31.

Beetham, H., McGill, L. \& Littlejohn, A. (2009) Thriving in the 21st Century: Learning Literacies for a Digital Age, JISC, [online] Available at: www.jisc.ac.uk/media/documents/ projects/lidaexecsumjune2009.pdf

Belshaw, D. (2012) The Essential Elements of Digital Literacies, [online] Available at: http:// www.slideshare.net/dajbelshaw/the-essential-elements-of-digital-literacies

Brandt, D. (2009) Literacy and Learning: Reflections on Writing, Reading, and Society, Wiley and Sons, San Francisco.

Brice-Heath, S. (1983) Way with Words: Language, Life and Work in Communities and Classrooms, Cambridge University Press, Cambridge.

Briggs, A. \& Burke, P. (2010) Social History of the Media: From Gutenberg to the Internet, 3rd edn, Polity Press, Cambridge UK/Malden USA.

Carrington, V. \& Robinson, M. (2009) Digital Literacies: Social Learning and Classroom Practices, SAGE, London.

Castells, M. (2010) The Rise of the Network Society, 2nd edn, Wiley-Blackwell, Chichester.

Clarke, J. (2002) 'A new kind of symmetry? Actor-network theories and the new literacy studies', Studies in the Education of Adults, vol. 34, no. 2, pp. 107-122.

Conole, G. (2008) 'New schemas for mapping pedagogies and technologies', Ariadne, no. 56, [online] Available at: http://www.ariadne.ac.uk/issue56/conole/

Cooper, M. \& Selfe, C. (1990) 'Computer conferences and learning: authority, resistance and internally persuasive discourse', College English, vol. 52, pp. 847-69.

Economic and Social Research Council (ESRC). (2011) Literacy in the Digital University Seminar Series, [online] Available at: http://www.esrc.ac.uk/my-esrc/grants/RES-451-260765/read

Fenwick, T. \& Edwards, R. (2010) Actor Network Theory in Education, Routledge, London.

Gee, J. (1990) Social Linguistics and Literacies: Ideology in Discourses, Falmer Press, London.

Gilster, P. (1997) Digital Literacy, John Wiley and Sons, Chichester.

Goodfellow, R. (2009) Literacy in the Digital University Blog, [online] Available at: http:// literacyinthedigitaluniversity.blogspot.co.uk/2009/10/lit-meets-tel.html

Goodfellow, R. (2011) 'Literacy, literacies, and the digital in higher education', Teaching in Higher Education, vol. 16, no. 1, pp. 131-144.

Goodfellow, R. \& Lea, M. (2007) Challenging E-learning in the University: A Literacies Perspective, Society for Research into Higher Education/Open University Press/ McGraw-Hill, Maidenhead.

Goodfellow, R. \& Lea, M., (eds) (2013). Literacy in the Digital University: Critical Perspectives on Learning, Scholarship and Technology (Research into Higher Education), Routledge, Taylor \& Francis, London/New York.

Gourlay, L. (2013) 'Cyborg literacies?' The construction of the hybrid subject in higher education,' in Digital Identity and Social Media, eds S. Warburton \& S. Hatzipanagos, IGI Global, London, pp. 29-36.

Gourlay, L. (forthcoming) 'Creating time: students, technologies and temporal practices in higher education,' E-learning and Digital Media, vol. 11, no. 1.

Gourlay, L. \& Oliver, M. (2013) 'Beyond 'the social': digital literacies as sociomaterial practice,' in Literacy in the Digital University: Critical Perspectives on Learning, Scholarship and Technology (Research into Higher Education), eds R. Goodfellow \& M. Lea, Routledge, Taylor \& Francis, London/New York, pp. 79-94. 


\section{Gourlay et al.}

Graff, H. (1987) The Legacies of Literacy: Continuities and Contradictions in Western Culture and Society, Indiana University Press, Bloomington, IN.

Hamilton, M. (2011) 'Unruly practices: what a sociology of translations can offer to educational policy analysis', in, eds Fenwick, T. \& Edwards, R. Journal of Educational Philosophy and Theory, Special Issue on Actor Network Theory 43(S1), 55-75.

Hayles, K. (1999) How We Became Posthuman: Virtual Bodies in Cybernetics, University of Chicago Press, London.

Hayles, K. (2012) How We Think: Digital Media and Contemporary Technogenesis, University of Chicago Press, London.

Haythornthwaite, C. \& Wellman, B. (2002) The Internet in Everyday Life. Wiley-Blackwell, Oxford/Maldon, USA.

Ivanic, R. (1998) Writing and Identity: The Discoursal Construction of Identity in Academic Writing, Peter Benjamins, Amsterdam.

Ivanic, R., et al. (2009) Improving Learning in College: Rethinking Literacies across the Curriculum, Routledge, London.

Jewitt, C. \& Kress, G. (2003) Multimodal Literacy, Peter Lang, Oxford.

Jones, C., Ferreday, D. \& Hodgson, V. (2008) 'Networked learning, a relational approach: weak and strong ties', Journal of Computer Assisted Learning, vol. 24, pp. 90-102.

Lankshear, C. \& Knobel, M. (2005) 'Digital literacies: policy, pedagogy and research considerations for education', Plenary address given at the ITU Conference, Oslo, 20 October.

Lankshear, C. \& Knobel, M. (2008) Digital Literacies: Concepts, Policies and Practices, Peter Lang, Oxford.

Law, J. (2009) 'Actor-network theory and material semiotics', in The New Blackwell Companion to Social Theory, ed. B. Turner, Oxford, pp. 141-158.

Lea, M. (1994) 'I thought I could write until I came here: student writing in higher education', in Improving Student Learning: Theory and Practice, ed. G. Gibbs, Oxford Centre for Staff Development, Oxford.

Lea, M. (2004) 'The new literacy studies, ICTs and learning in higher education', in Doing Literacy Online: Teaching, Learning and Playing in an Electronic World, eds I. Snyder \& C. Beavis, Hampton Press, Cresskill, NJ, pp. 3-24.

Lea, M. (2013) 'Reclaiming literacies: competing textual practices in a digital higher education', Teaching in Higher Education, vol. 18, no. 1, pp. 106-118.

Lea, M. \& Jones, S. (2011) 'Digital literacies in higher education: exploring textual and technological practice', Studies in Higher Education, vol. 36, no. 4, pp. 377-393.

Lea, M. \& Stierer, B. (2009) 'Lecturers' everyday writing as professional practice in the university as workplace: new insights into academic literacies', Studies in Higher Education, vol. 34 , no. 4, pp. 417-428.

Lea, M. \& Street, B. (1998) 'Student writing in higher education: an academic literacies approach', Studies in Higher Education, vol. 23, no. 2, pp. 157-172.

Lea, M. R. (2007) 'Emerging literacies in online learning', Journal of Applied Linguistics, vol. 4, no. 1 , pp. $79-100$.

Leander, K. M. \& McKim, K. K. (2003) 'Tracing the everyday 'sitings' of adolescents on the Internet: a strategic adaptation of ethnography across online and offline spaces', Education, Communication \& Information, vol. 3, no. 2, pp. 211-240.

Lillis, T. (1997) 'New voices in academia? The regulative nature of academic writing conventions', Language and Education, vol. 11, no. 3, pp. 182-199.

Lillis, T. (2001) Student Writing: Access, Regulation, Desire. Routledge, London.

Lillis, T. (2009) 'Bringing writers' voices to writing research: talk around texts', in Why Writing Matters: Issues of Access and Identity in Writing Research and Pedagogy, eds A. Carter, T. Lillis \& S. Parkin, Benjamins, Amsterdam, pp. 169-187.

Morgan, W., Russell, A. \& Ryan, M. (2000) 'Informed opportunism: teaching for learning in uncertain contexts of distributed education', in Distributed Learning: Social and Cultural Approaches to Practice, eds M. Lea \& K. Nicoll, Routledge Falmer, London, pp. $38-55$.

Orlikowski, W. (2000) 'Using technology and constituting structures: a practice lens for studying technology in organizations', Organizational Science, vol. 11, no. 4, pp. 404-428. 
Pahl, K. \& Rowsell, J. (2010) Artifactual Literacies: Every Object Tells a Story, Teachers College Press, New York.

Pardoe, S. (2000) 'Respect and the pursuit of 'symmetry' in researching literacy and student writing', in Situated Literacies: Reading and Writing in Context, eds D. Barton, M. Hamilton \& R. Ivanic, Routledge, London/New York. pp. 149-166.

Scollon, R. \& Scollon, S. (2004) Nexus Analysis: Discourse and the Emerging Internet. Routledge, London.

Selfe, C. \& Hawisher, G. (2004) Literate Lives in the Information Age: Narratives of Literacy from the United States, Lawrence Erlbaum, Mahwah, NJ.

Steinkuehler, C. (2007) 'Massively multiplayer online gaming as a constellation of literacy practices', Elearning and Digital Media, vol. 4, no. 3, pp. 297-318.

Street, B. (1985) Literacy in Theory and Practice, Cambridge University Press, Cambridge.

Thesen, L. \& Van Pletzen, E., (eds) (2006) Academic Literacy and the Languages of Change, Continuum, London.

Tummons, J. \& Hamilton, M. (2012) 'Institutional ethnography, literacy and the materialities of learning and teaching', Paper Presented to the Annual BERA Conference, Manchester, UK, September.

Welch, K. E. (1999) Electric Rhetoric: Classical Rhetoric, Oralism, and a New Literacy, MIT Press, Boston.

Weller, M. (2009) 'Using learning environments as a metaphor for educational change', On the Horizon, vol. 17, no. 3, pp. 181-189.

Williams, B. (2009) Shimmering Literacies: Popular Culture and Reading and Writing Online, Peter Lang, New York.

Williams, B. (2013) 'Control and the classroom in the digital university: the effects of course management systems on pedagogy', in Literacy in the Digital University: Critical Perspectives on Learning, Scholarship and Technology, eds R. Goodfellow \& M. Lea, Routledge, London, pp. 173-184.

Zappen, J. P. (2005) 'Digital rhetoric: toward an integrated theory', Technical Communication Quarterly, vol. 14, no. 3, pp. 319-325. 